\title{
Selvspising forlenger livet
}

Autofagi betyr «selvspising» på gresk og betegner cellens nedbrytning og resirkulering av egne bestanddeler. Nobelprisen i fysiologi eller medisin for 2016 ble tildelt Yoshinori Ohsumi (f.1945) for hans oppdagelser av mekanismer for autofagi i gjær. Ved induksjon av autofagi vil deler av cellens cytoplasma omsluttes av membraner (autofagosomer) som fusjonerer med lysosomet, cellens nedbrytnings- og gjenvinningsstasjon. Nedbrytningsproduktene blir så resirkulert som byggemateriale eller brukes til energiproduksjon for cellen. Autofagi er viktig for å fjerne cellens avfallsprodukter, som defekte organeller og proteinaggregater. Opphopning av disse kan ellers føre til sykdommer som kreft og nevrodegenerative lidelser.

Lenge manglet man gode analysemetoder for å studere autofagi. I begynnelsen av 1990-årene identifiserte Yoshinori Ohsumi spesifikke gener som har betydning for prosessen i gjær. Dette la grunnlaget for videre studier av autofagi i ulike dyremodeller, som viste at autofagi er viktig for normal utvikling og kan hindre utvikling av ulike sykdommer.

Da Ohsumi etablerte sitt laboratorium i 1988, bestemte han seg for å studere autofagi i gjærceller, fordi disse er godt egnet for genetiske studier (som da var vanskelig i humane celler), og fordi de fleste gener og cellulære prosesser er konservert i humane celler. Ohsumi baserte sine eksperimenter på funn gjort i studier av celler fra pattedyr. Disse viste blant annet at autofagi aktiveres når cellene dyrkes under næringsfattige betingelser (sult). Norske Per Seglen er en av pionerene $\mathrm{i}$ autofagifeltet $\mathrm{g}$ har bidratt med mange viktige oppdagelser og analysemetoder for å måle autofagi i celler fra rottelever $(1,2)$. For å undersøke om gjærceller har autofagi begynte Ohsumi med å karakterisere autofagi i celler dyrket under næringsfattige forhold. Han benyttet gjærstammer med defekt nedbrytning i vakuolen (lysosomet kalles vakuolen i gjær) og fant at i «utsultede» celler ble vakuolen fylt av autofagimembraner som inneholdt deler av cellens eget materiale, som ribosomer, mitokondrier og glykogengranuler (3). Eksperimentene demonstrerte ikke bare at også gjærceller har autofagi, men la grunnlag for videre studier hvor Ohsumi kunne identifisere og studere de molekylære mekanismene involvert i prosessen.

Gjærceller med defekt nedbrytning ble utsatt for et kjemisk stoff som induserte tilfeldige DNA-mutasjoner, og så sultet, for å indusere autofagi. Tanken var at gjærceller med mutasjoner i gener som er viktige for autofagi, ville vise redusert akkumulering av cellulært materiale i vakuolen. Denne strategien var vellykket og førte til oppdagelsen av det første autofagigenet - apg1. Ohsumi fant videre 14 andre apg-gener (4). Vi vet i dag at mer enn 30 gener (nå kalt «autophagy-related», Atg) er involvert i autofagi. Videre studier av Ohsumi og medarbeidere i 1990-årene førte til karakterisering av funksjonen til de ulike $\mathrm{Atg}$-proteinene. En av de viktigste oppdagelsene ble gjort i 2000 da de fant at proteinet $\operatorname{Atg} 8$ konjugeres kovalent til autofagimembranen og derved kan brukes som en markør for autofagi $(5,6)$.

Det virkelige gjennombruddet kom tidlig på 2000-tallet, da man ved bruk av autofagidefekte modellorganismer som mus, banan- fluer og C. elegans viste at autofagi er viktig for å beskytte oss mot sykdommer som kreft og nevrodegenerering og hindre aldring $(7,8)$. Økt autofaginivå kan forlenge levetiden til en organisme (9). Autofagi settes i gang og oppreguleres ved sult, og flere studier har vist at økt autofagi er viktig for den livsforlengende effekten av kalorirestriksjon (10). Dette forklares primært med at den «oppryddingen» i cellene som autofagi står for, bidrar til å fjerne skadelige komponenter som ødelagte mitokondrier, som genererer reaktive oksygenradikaler som kan føre til DNA-skade og kreft, og proteinaggregater, som kan føre til demens. Men for mye autofagi kan også ha skadelige effekter: Autofagi hindrer utviklingen av kreft, men kan samtidig bidra til økt overlevelse av kreftceller (7). Terapeutisk regulering av autofagi fremstår i dag som et svært attraktivt mål, og flere kliniske utprøvninger med hemmet autofagi i ulike krefttyper pågår. Videre viser nyere forskning at korttids fasting kan øke effekten av cellegift i mus med kreft, og at dette er autofagiavhengig (11). En detaljert forståelse av autofagi i ulike celletyper og vev, i tillegg til under ulike metabolske betingelser, kan derfor være nøkkelen til å forhindre sykdommer og forlenge livet. Dette har bidratt til at forskningsfeltet har fått et enormt oppsving det siste tiåret og nå nobelprisen.

\section{Anne Simonsen}

anne.simonsen@medisin.uio.no

Anne Simonsen (f. 1967) er professor ved Avdeling for molekylærmedisin, Institutt for medisinske basalfag, Universitetet i Oslo. Hun er utdannet molekylærbiolog og har jobbet med autofagi siden 1999, først som forsker ved Institutt for kreftforskning, Radiumhospitalet, og siden som professor og gruppeleder ved Institutt for medisinske basalfag.

\section{Litteratur}

1. Seglen PO, Gordon PB. 3-Methyladenine: specific inhibitor of autophagic/lysosomal protein degradation in isolated rat hepatocytes. Proc Natl Acad Sci U S A 1982; 79: 1889-92.

2. Seglen PO, Gordon PB, Poli A. Amino acid inhibition of the autophagic/lysosomal pathway of protein degradation in isolated rat hepatocytes. Biochim Biophys Acta 1980; 630: 103-18

3. Takeshige K, Baba M, Tsuboi S et al. Autophagy in yeast demonstrated with proteinase-deficient mutants and conditions for its induction. J Cell Biol 1992; 119: $301-11$

4. Tsukada M, Ohsumi Y. Isolation and characterization of autophagy-defective mutants of Saccharomyces cerevisiae. FEBS Lett 1993; 333: 169-74

5. Ichimura Y, Kirisako T, Takao T et al. A ubiquitin-like system mediates protein lipidation. Nature 2000; 408: 488-92.

6. Kirisako T, Baba M, Ishihara $\mathrm{N}$ et al. Formation process of autophagosome is traced with Apg8/Aut7p in yeast. J Cell Biol 1999; 147: 435-46.

7. Galluzzi L, Pietrocola F, Bravo-San Pedro JM et al. Autophagy in malignant transformation and cancer progression. EMBO J 2015; 34: 856-80.

8. Menzies FM, Fleming A, Rubinsztein DC. Compromised autophagy and neurodegenerative diseases. Nat Rev Neurosci 2015; 16: 345-57.

9. Simonsen A, Cumming RC, Brech A et al. Promoting basal levels of autophagy in the nervous system enhances longevity and oxidant resistance in adult Drosophila. Autophagy 2008; 4: 176-84

10. Madeo F, Zimmermann A, Maiuri MC et al. Essential role for autophagy in life span extension. J Clin Invest 2015; 125: 85-93.

11. Pietrocola F, Pol J, Vacchelli E et al. Caloric Restriction Mimetics Enhance Anticancer Immunosurveillance. Cancer Cell 2016; 30: 147-60. 